\title{
Leptin and leptin receptors during malaria infection in mice
}

\author{
Magdalena Pulido-Mendez ${ }^{1}$, Juan De Sanctis ${ }^{2}$ and Alexis Rodríguez-Acosta ${ }^{3}$ \\ ${ }^{1}$ Experimental Medicine Institute, Faculty of Medicine, Universidad Central de Venezuela, University City, 1041, Caracas, \\ Venezuela; \\ ${ }^{2}$ Immunology Institute, Faculty of Medicine, Universidad Central de Venezuela, University City, 1041, Caracas, Venezuela; \\ ${ }^{3}$ Section of Immunochemistry, Tropical Medicine Institute, Universidad Central de Venezuela, University City, 1041, Caracas, \\ Venezuela
}

Key words: leptin, Plasmodium berghei, malaria, soluble leptin receptor

\begin{abstract}
Leptin, which is involved in a range of physiological processes, could be an important factor in the pathogenesis of malaria. We found that levels of leptin in serum and urine in Plasmodium berghei-infected mice increased progressively after infection, reaching a maximum value on day 6 post-infection. Serum values were approximately five-fold higher in infected mice than in non-infected controls. A similar relation was found for values of leptin in urine. Soluble leptin receptor levels also increased significantly in serum, more or less in line with the leptin increase. Our work represents the first report of visibly augmented leptin and soluble leptin receptor secretion in malarial infection.
\end{abstract}

Leptin is a $16 \mathrm{kDa}$ hormone essentially formed by adipose cells, product of the $o b$ gene that regulates energy expenditure and appears to have many other functions. A broader role for leptin than regulation of adipose tissue mass has been suggested because this hormone seems to be involved in fertility control (Friedman and Halaas 1998), in the onset of puberty (Mantzoros et al. 1997) and in the regulation of immune response (Lord et al. 1998). In malaria, an association between overproduction of tumour necrosis factor (TNF- $\alpha$ ) and nitric oxide (NO) with severe pathological manifestations has been described (De Kossodo and Grau 1993, Prada and Kremsner 1995). It is known that leptin secretion can be regulated by inflammatory mediators such as interleukin-1 (IL-1) and TNF- $\alpha$ (Faggioni et al. 1998). Furthermore, leptin exerts central effects on hypothalamic-pituitary function and these effects might influence the severity of malaria disease. Disturbances in the hypothalamic-pituitary-adrenal axis during Plasmodium falciparum infection have been implicated in the pathogenic mechanism of severe malaria (Davis et al. 1997).

Since leptin is involved in a range of physiological processes, it could be an important factor in malarial infection development and outcome. In this work increased serum and urine leptin levels were found during the acute phase of Plasmodium berghei Vincke et Lips, 1948 infection in mice.

\section{MATERIALS AND METHODS} used.

Mice. Male mice of C57BL/6 strain weighing 18-22 g were

Parasites and experimental infection. A Plasmodium berghei strain from the Swiss Tropical Institute, Basel maintained by weekly intraperitoneal transfer of parasitised erythrocytes into naive mice, was used in all experiments.

Experimental infection in $\mathrm{C} 57 \mathrm{BL} / 6$ mice was accomplished by intraperitoneal inoculation of $1.2 \times 10^{6}$ parasitised red blood cells. The parasitaemia curve was performed throughout the experiment by counting infected erythrocytes in relation to 100 white blood cells. In two separate experiments, pooled serum and twenty-four hours pooled urine samples of ten infected animals, were collected at 3, 6, 9 and 12 days post-infection (p.i.). Serum samples were always obtained from 09:00 to 10:00. Pooled control samples, also collected from 09:00 to 10:00, were prepared from ten non-infected mice. The investigation complied with the norms taken from the Principles of Laboratory Animal Care, published by the US National Institute of Health (Anonymous 1985).

ELISA assay for leptin. Leptin levels were assessed in serum and urine samples using a commercial sandwich ELISA assay, Quantikine M (R\&D Systems, UK). Serum samples were processed according to manufacturer's instructions (diluted from 1:2 up to 1:20) and urine samples were dialyzed prior to the assay against PBS and were used without dilution. The values in serum and urine were corrected according to the original volume. The sensitivity of the assay was $40 \mathrm{pg} / \mathrm{ml}$ and the standard curve range between 40 and $4000 \mathrm{pg} / \mathrm{ml}$. The inter-assay and intra-assay variations were less than $5 \%$. The results in urine and serum samples were confirmed by immunoprecipitation (results not shown).

ELISA assay for soluble leptin receptor. A soluble form of leptin receptor has been described by Sinha et al. (1996) and usually was determined using gel exclusion profile and immunoprecipitation. We developed a simple competitive assay for soluble leptin receptor using the recombinant extracellular portion of the murine leptin receptor (R\&D Systems, UK), labelled in the laboratory with peroxidase, and antibodies against the extracellular portion of the receptor 
purified from goat (R\&D Systems, UK) and rabbit (Santa Cruz Biotechnology, USA). ELISA plates (Maxisorp, Nunc, Finland) were used to adsorb the goat IgG (R\&D Systems, UK) using standard procedures, and subsequently the recombinant leptin receptor protein-peroxidase was incubated in the plates for 1 hour at $37^{\circ} \mathrm{C}$. A standard curve was performed using different concentrations of the recombinant protein. After the incubation, the plates were washed extensively with PBS-Tween $0.05 \%$ and then incubated with the TMB substrate kit (Vector, USA). The range of the optical density was between 0.05 for $2 \mathrm{ng}$ of protein up to 2.0 for 100 ng of protein $(\mathrm{r}=0.9, \mathrm{n}=10)$. The competitive assay consisted in adding $0.2 \mathrm{ml}$ of serum samples for one hour at $37^{\circ} \mathrm{C}$, washing and then incubating with the recombinant protein-peroxidase. An inhibition of peroxidase-derived colour was directly proportional to soluble leptin receptor concentration in serum. As a secondary control of specificity, prior to the competitive assay, serum samples were incubated with the rabbit antibody anti-soluble leptin receptor, and precipitated with gel coated anti-rabbit IgG. No inhibition was observed in the assay. The specificity of the assay was $95 \%$ and the intra-assay and inter-assay differences were less than $10 \%$ for 50 control samples. The range of the assay was between 2 and $100 \mathrm{ng} / \mathrm{ml}$.

\section{RESULTS}

Parasitaemia was monitored in all infected mice every 3 days during the course of infection. There was an increase of infected erythrocytes from day 6 to day 9 p.i., reaching a count of 1500 red blood cells/100 white blood cells on day 9 p.i. After that the parasitaemia decreased in the final stage of infection.

In two experiments, levels of serum leptin and of urine leptin in infected animals showed a progressive increase, reaching a maximum value on day 6 p.i. (Fig. 1). Serum values were approximately four-fold or five-fold higher in infected animals than in the non-infected controls. A similar relation was found for urine values. Leptin concentration dropped on day 12 p.i., nearing that of the control (day 0 ).

Fig. 2 shows that values of soluble leptin receptor also increased in serum, more or less matching the increment in leptin levels.

\section{DISCUSSION}

In experimental animals, leptin levels are intensely increased by inflammatory induction, such as bacterial endotoxin lipopolysaccharide (LPS) stimuli, and by the injection of pro-inflammatory cytokines such as IL-1 and TNF- $\alpha$ (Voegeling and Fantuzzi 2001). The immune response in rodent Plasmodium berghei malaria seems to have a Th1-like pattern of cytokine production (De Kossodo and Grau 1993). This suggests a predominant Th1 response during the acute phase of the infection. Th1 cells secreting interferon- $\gamma$ (IFN- $\gamma$ ) and interleukin-2 (IL-2) would activate macrophages to produce pro-inflammatory cytokines such as IL-1,

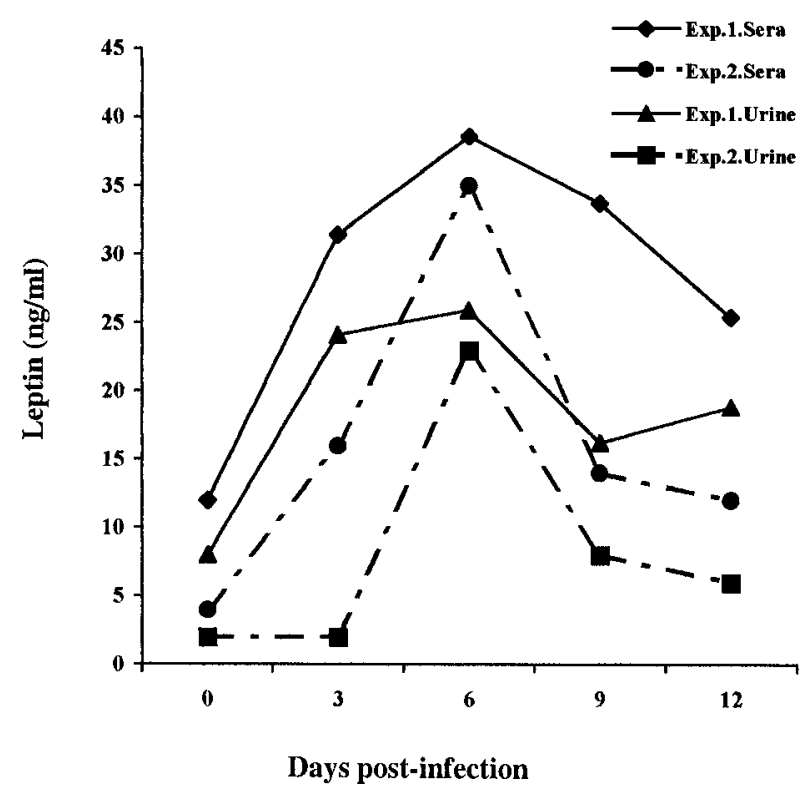

Fig. 1. Leptin levels in mouse sera and urines. Each point corresponds to leptin value obtained in pooled sera from 10 mice. Groups of infected animals (10 at each date) were sacrificed at 3, 6, 9 and 12 days post-infection. Pooled urine samples were collected from the same infected mice in a $24 \mathrm{~h}$ period before sacrifice. Control mice values (sera and urines) were obtained from normal animals and they are represented by the 0 day values.

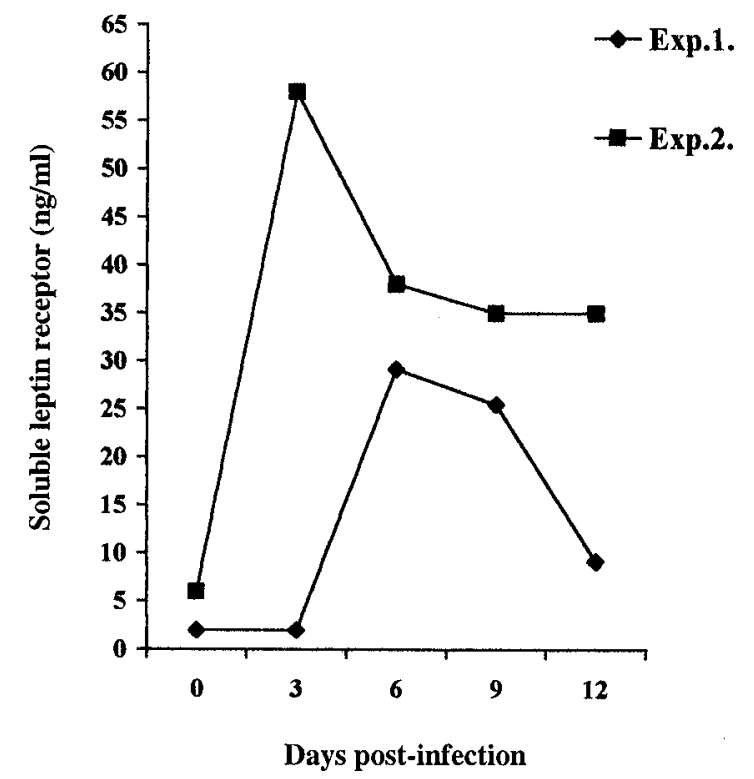

Fig. 2. Soluble leptin receptor levels in mouse sera. Each point corresponds to soluble leptin receptor value obtained in pooled sera from 10 mice. Groups of infected animals (10 at each date) were sacrificed at 3, 6, 9 and 12 days post-infection. Control mice values were obtained from normal animals and they are represented by the 0 day values. The analysed sera in these experiments corresponded to the same animals studied for leptin level values. 
interleukin-6 (IL-6) and TNF- $\alpha$. Recently, IL-1 and TNF- $\alpha$ have been implicated in leptin secretion regulation (Mantzoros et al. 1997, Faggioni et al. 1998, Corica et al. 1999). These observations suggest that increased leptin production could be found in diverse infectious diseases characterised by a Th1 profile of cytokine production and in other acute specific or nonspecific inflammatory processes as a normal component of inflammatory response. In this context, increased leptin levels have been associated with anorexia induced by the parasite Nippostrongylus brasiliensis infection in rats (Roberts et al. 1999). The kinetics of leptin production during inflammation and infection is similar to that of cytokine production (Arnalich et al. 1999). In addition, mean serum leptin concentrations were substantially augmented in critically ill septic patients (Arnalich et al. 1999). Voegeling and Fantuzzi (2001) also tested free and bound leptin and soluble leptin receptors during inflammation in mice, observing an increased value of soluble factor after LPS injection.

This is the first time that an apparently augmented leptin secretion in malarial infection has been reported. Leptin levels in serum and urine rose during Plasmodium berghei infection following a similar pattern to IFN- $\gamma$ and nitric oxide (NO) increases (unpublished data).
Nitric oxide and TNF- $\alpha$ overproduction have been proposed as inducing pathological changes in complicated malaria. In this context, TNF- $\alpha$ overproduction could be linked to raised leptin levels. Increased leptin levels could contribute to the pathological effects, through the influence of leptin on the wasting syndrome (Trayhurn et al. 1999) and through its role in causing a positive feedback loop in the inflammatory process. In certain experimental preparations, leptin is able to produce Th1 cell activation and augmented IFN- $\gamma$ and IL-2 secretion (Lord et al. 1998), which may provide an additional pathogenic mechanism to bring about the malariaassociated pathology. Leptin seems to be a modulating factor of T cell immune response. (Lord et al. 1998).

In our results, increased leptin levels were coincident with a rise in soluble leptin receptor. This observation is in line with other reports (Friedman and Halaas 1998). The regulation mechanism of soluble-receptor production and its physiological significance in leptin action remain a matter of speculation.

Acknowledgements. We thank Professor Mark Gregson for reviewing the English of the manuscript. We also thank an anonymous referee and the editor for helpful advice.

\section{REFERENCES}

ANONYMOUS 1985: Principles of Laboratory Animal Care. National Institute of Health, Maryland, USA, $96 \mathrm{pp}$.

ARNALICH F., LOPEZ J., CODOCEO R., JIMENEZ M., MADERO R., MONTIEL C. 1999: Relationship of plasma leptin to plasma cytokines and human survival in sepsis and septic shock. J. Infect. Dis. 180: 908-911.

CORICA F., ALLEGRA A., CORSONELLO A., BUEMI M., CALAPAI G., RUELLO A., NICITA MAURO V., CERUSO D. 1999: Relationship between plasma leptin levels and the tumor necrosis factor-alpha system in obese subjects. Int. J. Obes. Rel. Metabol. Disord. 23: 355-360.

DAVIS T.M., LI T.A., TRAN Q.B., ROBERTSON K., DYER J.R., PHAN T.D., MEYER D., BEAMAN M.H., TRINH K.A. 1997: The hypothalamic-pituitary-adrenocortical axis in severe falciparum malaria: effects of cytokines. J. Clin. Endocrinol. Metabol. 82: 3029-3033.

DE KOSSODO S., GRAU G.E. 1993: Profiles of cytokine production in relation with susceptibility to cerebral malaria. J. Immunol. 151: 4811-4820.

FAGGIONI R., FANTUZZI G., FULLER J., DINARELLO C.A., FEINGOLD K.R., GRUNFELD C. 1998: IL-1 beta mediates leptin induction during inflammation. Am. J. Physiol. 274: R204-208.

FRIEDMAN J.M., HALAAS J. 1998: Leptin and the regulation of body weight in mammals. Nature 395: 763-770.

LORD G.M., MATARESE G., HOWARD J.K., BAKER R.J., BLOOM S., LECHLER R. 1998: Leptin modulates the T- cell immune response and reverses starvation-induced immunosuppression. Nature 394: 897-901.

MANTZOROS C.S., FLIER J.S., ROGOL A.D. 1997: Longitudinal assessment of hormonal and physical alterations during normal puberty in boys. Raising leptin levels may signal the onset of puberty. J. Clin. Endocrinol. Metabol. 82: 1066-1070.

PRADA J., KREMSNER P.G. 1995: Enhanced production of reactive nitrogen intermediates in human and murine malaria. Parasitol. Today 11: 409-410.

ROBERTS H.C., HARDIE L.J., CHAPPELL L.H., MERCER J.G. 1999: Parasite-induced anorexia: leptin, insulin and corticosterone responses to infection with the nematode, Nippostrongylus brasiliensis. Parasitology 118: 117-123.

SINHA M.K., OPENTANOVA I., OHANNESIAN J.P., KOLACZYNSKI J.W., HEIMAN M.L., HALE J., BECKER G.W., BOWSHER R.R., STEPHENS T.W., CARO J.F. 1996: Evidence of free and bound leptin in human circulation. Studies in lean and obese subjects and during short-term fasting. J. Clin. Invest. 98: 1277-1282.

TRAYHURN P., HOGGARD N., MERCER J.G., RAYNER D.V. 1999: Leptin: fundamental aspects. Int. J. Obes. Rel. Metabol. Disord. 23, Suppl 1: 22-28.

VOEGELING S., FANTUZZI C. 2001: Regulation of free and bound leptin and soluble leptin receptors during inflammation in mice. Cytokine14: 97-103. 